\title{
UNSUR MORAL DALAM KARYA FIKSI
}

\author{
Sri Wahyuni D. \\ Fakultas Sastra, Universitas Muslim Indonesia \\ Jalan Urip Sumoharjo KM 5, Makassar \\ Sridarsis@gmail.com
}

\begin{abstract}
Abstrak: Unsur moral dalam karya fiksi tidak terbatas, Moral dalam karya fiksi biasanya mencerminkan pandangan hidup pengarang yang bersangkutan pada pandangnnya tentang nilai-nilai kebenaran dalam hidup yang disampaikan kepada pembaca.Pesan moral pada karya fiksi menitikberatkan pada sifat kodrati manusia yang hakiki, dengan kata lain bahwa manusia tidak hanya ditentukan oleh aturan-aturan yang dibuat oleh manusia itu sendiri. Moral dalam karya fiksi tidak pernah terlepas dari pengertian yang baik. Tiap cerita fiksi masing-masing mengandung dan menawarkan pesan moral, tentunya banyak sekali jenis dan wujud ajaran moral. Jenis dan wujud pesan moral yang terdapat dalam karya fiksi bertantung pada keyakinan, keinginan, dan interes pengarang yang bersangkutan. Jenis ajaran moral boleh dikatakan bersifat tidak terbatas. Penyempaian pesan moral pada karya fiksi tentunya tidak lepas dari kritik sosial dan kritik agama yang ingin disampaikan oleh penulis. Demikian juga dengan bentuk penyampaian langsung dan tidak langsung yang ingin dihadirkan oleh penulis di dalam karya fiksi sebagai nasihat dan petuah bagi pembaca.
\end{abstract}

Kata kunci: unsur moral, kritik sosial, pesan moral

\section{PENDAHULUAN}

Secara umum moral merupakan baik buruknya perbuatan, sikap, dan kewajiban mengenai akhlak, budi pekerti, dan susila yang diterima oleh orang lain. Pada (KBBI, 2016) dijelaskan bahwa moral merupakan kondisi mental yang membuat orang tetap berani, bersemangat, bergairah, berdisiplin serta keadaan perasaan sebagaimana terungkap dalam perbuatan. Dalam pengertian lain juga disebutkan bahwa moral jika dilihat dari dikatomi yang lain menjelaskan bahwa moral sesuatu yang ingin disampaikan oleh pengarang kepada pembaca dan merupakan makna yang terkandung dalam karya sastra, seperti halnya dalam penentuan tema seringkali bermakna moral yang ingin disampaikan oleh penulis karya. Pada dasarnya fiksi mengandung penerapan moral serta sikap dan tingkah laku parah tokoh sesuai dengan yang ada pada karya fiksi. Kemudian melalui tokohtokoh itulah pembaca dituntut dapat mengambil hikmah dari karya fikis tersebut. Pesan moral pada karya fiksi menitikberatkan pada sifat kodrati manusia yang hakiki, dengan kata lain bahwa manusia tidak hanya ditentukan oleh aturan-aturan yang dibuat oleh manusia itu sendiri. Moral dalam karya fiksi tidak pernah terlepas dari pengertian yang baik. Artinya, pembaca diharapkan mampu menemukan pesan moral yang baik didalam karya fiksi tersebut, meskipun hal itu dilihat dari sisi tingkah laku tokoh yang kurang baik. 


\section{PEMBAHASAN}

\section{Unsur-unsur Moral Dalam Fiksi}

\section{Hakikat Moral}

Moral merupakan makna yang terkandung dalam sebuah karya fiksi, makna yang disarankan lewat cerita. Adakalanya moral diidentikkan sesuatu yang terkandung, dapat ditafsirkan, dan diambil dari cerita. Unsur-unsur moral yang terdapat pada karya fiksi dapat mencakup masalah yang boleh dikatakan bersifat tidak terbatas. Ia dapat mencakup seluruh persoalan hidup dan kehidupan, seluruh persoalan yang menyangkut harkat dan martabat manusia.

Moral dalam karya fiksi biasanya mencerminkan pandangan hidup pengarang yang bersangkutan pada pandangnnya tentang nilai-nilai kebenaran dalam hidup yang disampaikan kepada pembaca. Penulis menceritakan model kehidupan yang diidealkannya yang senantiasa menawarkan pesan moral sesuai dengan sifat-sifat luhur kemanusiaan serta memperjuangkan harkat dan martabat manusia.

Sifat-sifat luhur kemanusiaan tersebut pada hakikatnya bersifat universal. Artinya, sifat-sifat itu dimiliki dan diyakini kebenarannya oleh manusia sejagad. Ia tidak hanya bersifat kebangsaan, apalagi keseorangan, walau memang terdapat ajaran moral-kesusilaan yang hanya berlaku dan diyakini oleh kelompok tertentu. sebuah cerita fiksi yang menawarkan pesan moral yang bersifat universal, biasanya akan diterima kebenarannya secara universal pula dan memungkinkan untuk menjadi sebuah karya yang bersifat sublime-walau untuk yang disebut juga (terlebih) ditentukan oleh berbagai unsur intrinsik yang lain. Misalnya, cerita fiksi yang menenagkan perjuangan tokoh putih terhadap tikoh hitam yang jahat tampaknya dapat diterima oleh manusia sejagad sebagai ajaran moral yang memang harus diperuangkan.

Persoalan manusia dengan dirinya sendiri dapat berbagai macam jenis sesuai dengan stingkat intesitasnya. Hal ini kemudian yang tak lepas dari bagaimana hubungan antar sesama manusia dengan Tuhan. Seperti bagaimana harga diri, eksistensi diri, rasa takut, bahagia, percaya diri, dendam dan lainnya yang melibatkan kondisi kejiawaan manusia. Kenny (1996:89) mengemukakan bahwa moral dalam karya sastra biasanya dimaksudkan sebagai suatu saran yang berhubungan dengan ajaran moral tertentu yang bersifat praktis, yang dapat diambil (dan ditafsirakan), lewat cerita yang bersangkutan oleh pembaca.

\section{Sastra dan Pembentukan Karakter}

Adanya unsur moral dalam karya sastra sering dikaitkan dengan fungsi sastra bagi pembentukan karakter pembaca terutama anak dalam konteks pembelajaran sastra. Pembacaan dan pembelajaran sastra bermuara pada afeksi, bukan kognisi. Aspek afektif itu sering dikaitkan dengan menyukai dan bahkan mencintai sastra. Sastra lebih berperan menggerakkan hati dan perasaan daripada mengajarkan pengertian kognitif. Selain itu sastra mampu memberikan kesenangan dan kenikmatan, namun di dalamnya juga terkandung "memberi kemanfaatan". Manfaat yang dapat diberikan pada karya sastra adalah dengan melibatkan berbagai aspek kehidupan yang menunjang atau memengaruhi cara berpikir, bersikap, berperasaan, bertindak secara verbal atau nonverbal. Atau minimal, ada perubahan perubahan dalam memandang sesuatu terkait sebelum dan sesudah membaca 
cerita fiksi. Dengan demikian sastra menjadi karya yang mencerminkan sikap hidup masyarakat di mana dan kapan karya itu diciptakan.

\section{Jenis dan Wujud Pesan Moral}

Tiap cerita fiksi masing-masing mengandung dan menawarkan pesan moral, tentunya banyak sekali jenis dan wujud ajaran moral. Jenis dan wujud pesan moral yang terdapat dalam karya fiksi bertantung pada keyakinan, keinginan, dan interes pengarang yang bersangkutan. Jenis ajaran moral boleh dikatakan bersifat tidak terbatas. Sebuah novel tentu saja dapat menwarkan pesan moral itu salah satu, dua atau ketiganya sekaligus. Bahkan secara garis besar persoalan mengenai hidup dan kehidupan manusia mencakup tiga hal, yakni : (1) hubungan manusia dengan diri sendiri, (2) hubungan manusia dengan manusia lain termasuk juga hubungan dengan lingkungan alam, (3) hubungan manusia dengan Tuhan-Nya.Persoalan manusia dengan dirinya sendiri dapat bermacam-macam jenis dan intensitasnya. Hal itu tentu saja tak lepas dengan hubungan antar sesame dan Tuhannya.

\section{Pesan Religius dan Kritik Sosial}

Pesan moral yang berwujud moral religius, termasuk di dalamnya yang bersifat keagamaan, dan kritik sosial yang banyak ditemukan dalam karya fiksi atau dalam genre sastra yang lain. Kedua hal tersebut merupakan "lahan" yang banyak memberikan inspirasi bagi para penulis khususnya penulis sastra Indonesia modern. Hal itu mungkin disebabkan banyaknya masalah kehidupan yang tidak sesuai dengan harapannya dan kemudian mereka mencoba menwarkan sesuatu yang diidealkan.

\section{Pesan Religius dan Keagamaan}

Unsur religius dan keagamaan dalam sastra aadalah suatu keberadaan sastra itu sendiri. Bahkan sastra tumbuh dari sesuatu yang bersifat religius. Istilah religius membawa konotasi pada makna agama. Religius dan agama memang erat berkaitan, berdampingan, bahkan dapat melebur dalam satuk kesatuan, namun sebenarnya keduanya menyaran pada makna yang berbeda. Dengan demikian religius bersifat mengatasi lebih dalam dan lebih luas dari agama yang tampak formal dan resmi. Moral religius menjunjung tinggi sifat-sifat manusiawi hati nurani yang dalam harkat martabat serta kebebasan pribadi yang dimiliki oleh manusia. Kehadiran unsur religius dan keagamaan dalam sastra itu sendiri adalah setua keberadaan sastra itu sendiri. Bahkan sastra tumbuh dari sesuatu yang bersirat religius. Seperti pada kutipan Manginwiajaya (1982:11) tentang "Religius" yang membawa konotasi pada makna agama.

Agama sebagai keyakinan penuh Tokoh: seperti pada novel Hamamah Salam karya Najib Al Kaelani terdapat pesan moral religius akan kenikmatan yang Allah limpahkan kepada hambaNya. Seseorang telah diberikan kekaya an hidup dalam kemakmuran hendaklah ia bersyukur dan bersikap belas kasih serta dermawan kepada orang miskin. Karya ini memberikan pencerahan akan seseorang yang sudah menunaikan rukun Islam yang kelima yaitui badah Haji, hendaklah mencerminkan sikap sebagai muslim sejati seperti yang ditokohkan Jalaluddin dan Syeikh Abdul Baqi. Sikap kepeduliannya mencerminkan sikap percaya akan kasih Allah. Memberikan kemampuannya untuk berdakwah dan membela kebenaran atas kebijakan licik Abdul Wadud. Hal ini 
memberikan pesan religius yang berupa jihad untuk membel rakyat miskin. Dalam novel iniJ alaludin mencoba memberikan pencerahan dan penyadaran kepada Abdul wadud dalam Khutbah shalat jum'at, agar Abdul wadud bersikap adil dan tidak congkak. Pesan Religius yang dapat diambil adalah dengan khutbah juma'at dapat memberikan nilai-nilai kebaikan dan dapat mempersatukan persaudaraan. Dengan ayat-ayat AlQur-an seseorang sadar akan tindakannya yang buruk dan berubah menjadi baik. Selain itu pesan religious yang dapat diambil adalah apapun penderitaan dan kesulitan yang dihadapi jangan sekali-kali meninggalkan kewajiban yaitu sholat.

Tarik-menarik Religiositas dengan Formalisme Hukum Agama : unsur agama dalam karya-karya Navis seperti dalam "Robohnya Surau Kami", "Datang dan Perginya", dan Kemarau, berbeda halnya dengan contoh karya di atas. Unsur-unsur keagamaan dan religiositas dihadirkan secara koheren dalam cerita " Robohnya Surau Kami” menceritakan kehidupan seorang penunggu surau yang hanya beribadah melulu dan melupakan urusan dunia, yang akhirnya bunuh diri. Pesan keagamaan yang disampaikan pada cerita rerita tersebut bahwa kehidupan dunia dan akhirat harus dijalani secara seimbang. Manusia boleh saja dan wieajibkan beribada secara sungguh-sungguh serta selalu mengingat Tuhan, tetapi manusia tidak bias terhindar dari kebutuhan duniawi.

\section{Pesan Kritik Sosial}

Sastra yang mengandung pesan dapat juga disebut sebagai sastra kritik yang biasanya akan lahir ditengah masyarakat jika terjadi hal-hal yang kurang beres dalam kehidupan sosial dan masyarakat.
Kritik sosial banyak ditemukan dalam karya fiksi atau dalam genre sastra yang lain. Hampir semua novel Indonesia sejak awal pertumbuhannya hingga dewasa ini boleh dikatakan menagandung unsur pesan kritik sosial walaupun dengan tingkat intensitas yang berbeda.

\section{Bentuk Penyampaian Pesan Moral}

Dari sisi tertentu cerita fiksi dapat dipandang sebagai bentuk manifestasi keinginan pengarang untuk mendialog, menawar, dan menyampaikan sesuatu. Sesuatu itu mungkin berupa padandangan tentang suatu hal, gagasan, moral atau amanat. Selain itu bentuk penyampaian pesan moral pada karya fiksi menyatakan adanya kejujuran dalam bentuk sikap dan kejujuran dalam bentuk amanat. Kejujuran dalam bentuk amanat inilah yang biasanya terdapat pada alur cerita yang ada pada karya fiksi. Mansyur (2016) menyatakan bahwa nilai kejujuran dalam karya fiksi merupakan penggambaran pada nila-nilai kehidupan, di mana pembaca mampu memahami secara tidak langsung melalui imajinasi yang bersumber pada amanat yang terkandung di dalam karya fiksi.

Secara umum dapat dikatakan bahwa bentuk penyampaian moral dalam karya fiksi berisfat langsung dan juga tidak langsung. Namun, sebenarnya pemilihan itu hanya demi praktisnya saja sebab mungkin saja ada pesan yang bersifat agak langsung.

\section{Bentuk Penyampaian Langsung}

Bentuk penyampaian moral yang bersifat langsung, boleh dikatakan identik dengan cara pelukisan watak tokoh yang bersifat uraian, telling, atau penjelasan, expository. Jika dalam teknik uraian pengarang secara langsung mendeskripsikan tokoh yang bersifat 
memberitahu atau memudahkan pembaca untuk memahaminya. Hal demikian itu pula yang terjadi dalam penyampaian pesan moral.

Jadi pesan moral yang ingin disampaikan dengan langsung dan ekspilit. Dan secara langsung memberikan nasihat dan petuah kepada pembaca.

\section{Bentuk Penyampaian Tidak Langsung}

Pesan dalam penyampaian tidak langsung hanya tersirat dalam cerita, berpadu secara koherensif dengan unsurunsur cerita yang lain. Jika dibandingkan dengan teknik pelukisan watak tokoh, cara ini sejalan dengan teknik ragaan, showing. Yang ditampilkan dalam cerita adalah peristiwa-peristiwa, konflik, sikap dan tingkah laku para tokoh dalam menghadapi peristiwa dan konflik itu, baik yang terlihat dalam tingkah laku verbal, fisik, maupun yang hanya terjadi dalam pikiran dan perasaannya. Sebaliknya dilihat dari pembaca, jika ingin memahami dan atau menafsirkan pesan itu, harus melakukannya berdasarkan cerita, sikap dan tingkah laku para tokoh tersebut.

\section{PENUTUP}

Karya sastra pada akhirnya tidak lepas dari bagaimana seorang penulis mampu membuat pembaca mengambil hikmah dari isi karya tersebut. Pesan moral tentunya sangat berpengaruh terhadap kehidupan manusia. Untuk itu kritik agama maupun kritik sosial sudah sepatutnya menjadi landasan agar manusia berbuat sesaui dengan kodratnya. Tak hanya itu pesan moral juga tentunya menjadi gambaran pada pembaca bahwa dalam menjalani kehidupan kita dituntut untuk menjadi pribadi yang baik dan mencerminkan nilai-nilai luhur kemanusiaan serta tidak lepas pada keyakinan agama yang masing-masing individu.

\section{DAFTAR PUSTAKA}

Diyah, Mamah. 2013. Makalah Moral Dalam Fiksi http://mamadiyah.blogspot.com/2013/11/makalah-moral-dalam-fiksi.html?m=1 http://sastra33.blogspot.com/2010/05/resume-buku-teori-pengkajian-fiksi.html?m=1 https://woroseto.wordpress.com/2013/12/09/unsur-dan-bentuk-penyampaian-moral-atauamanat-dalam-novel-hamamah-salaam-karya-najib-al-kaelani/amp

Kemendikbud. 2016. Kamus Besar Bahasa Indonesia Versi Daring. Jakarta: Badan Bahasa Kemendikbud.

Mangunwijaya 1982. Sastra dan Religiosita.Kansisus.Yogyakarta

Mansyur, Umar. 2016. Pemanfaatan Nilai kejujuran dalam Cerpen sebagai Bahan Ajar Berbasis Pendidikan Karakter. In Mengais Karakter dalam Sastra: HISKI Makassar (pp. 330-339). https://doi.org/10.17605/OSF.IO/Z4T3Y

Mansyur, Umar. 2018. Kiat dan Teknik Penulisan Skripsi bagi Mahasiswa.INA-Rxiv. https://doi.org/10.31227/osf.io/juds7

Nurgiyantoro, Burhan 2015. Teori Pengkajian Fiksi. Gadjah Mada University Press.Yogyakarta

Sastra33. 2012. Resume Buku “ Teori Pengkajian Fiksi” Karya Burhan Nurgiyantoro

Woroseto, (2013). Unsur dan Bentuk Penyampaian Moral atau Amanat dalam Novel 